\title{
Optimization of Multiple Injection Strategy in Modified Common Rail Direct Injection Diesel Engine Powered with Palm Oil Methyl Ester
}

\author{
Mahantesh Shivashimpi ${ }^{1,}$, , Sidramappa Alur ${ }^{1}$, Nagaraj Banapurmath ${ }^{2}$, Uday Kapale ${ }^{3}$ \\ ${ }^{1}$ Mechanical Engineering, Hirasugar Institute of Technology, Nidasoshi, Karnataka, India \\ ${ }^{2}$ Department of Mechanical Engineering, B. V. Bhoomaraddi College of Engineering and Technology, Hubballi, Karnataka, India \\ ${ }^{3}$ Mechanical Engineering, S. G. Balekundri Institute of Technology, Belagavi, Karnataka, India
}

\section{Email address:}

shivashimpi@gmail.com (M. Shivashimpi), saalur.mech@hsit.ac.in (S. Alur),nrbanapurmath@gmail.com (N. Banapurmath), uday_kapale@sgbitbgm.in (U. Kapale)

${ }^{*}$ Corresponding author

\section{To cite this article:}

Mahantesh Shivashimpi, Sidramappa Alur, Nagaraj Banapurmath, Uday Kapale. Optimization of Multiple Injection Strategy in Modified Common Rail Direct Injection Diesel Engine Powered with Palm Oil Methyl Ester. International Journal of Computational and Theoretical Chemistry. Vol. 7, No. 1, 2019, pp. 87-99. doi: 10.11648/j.ijctc.20190701.20

Received: March 21, 2019; Accepted: April 28, 2019; Published: May 26, 2019

\begin{abstract}
In this investigation, the common rail direct injection (CRDI) single cylinder four stroke diesel engine has made to modify in terms of toroidal reentrant combustion chamber (TRCC) shape and 7 holes CRDI nozzle injector. The current experimental study objective is to optimization of multiple injection strategy (MIS) in modified CRDI diesel engine powered with palm oil methyl ester (POME) B100 and diesel fuels. In the first phase of work, experiment results showed that slightly improved in brake thermal efficiency (BTE) and reduced emissions except oxides of nitrogen $\left(\mathrm{NO}_{\mathrm{x}}\right)$ for POME fuelled engine operates under optimized MIS, fuel injection timing (IT) of $-10^{\circ}$ before top dead center (BTDC) and 600 bar injection pressure (IOP) in modified CRDI diesel engine. In the second phase of work, the performance of modified CRDI diesel engine is improved by increasing IOP from 600 bar to 900 bar at same MIS and fuel IT. The second phase of experiment results showed that percentage of increase in BTE by $2.47 \%$, peak pressure (PP) by $13.69 \%$, heat release rate (HRR) by $17.64 \%$, $\mathrm{NO}_{\mathrm{X}}$ by $11.70 \%$ and percentage of decreased in ignition delay (ID) by $29.62 \%$, combustion duration (CD) by $13.79 \%$, unburnt hydrocarbon (UBHC) by $19.04 \%$, carbon monoxide (CO) by $14.28 \%$, smoke level by $20.93 \%$ as compared to first phase of work in modified CRDI diesel engine fuelled with POME.
\end{abstract}

Keywords: Palm Oil Methyl Ester, Common Rail Direct Injection, Toroidal Reentrant Shape, Multiple Injection Strategy, Injection Timing, Injection Pressure

\section{Introduction}

The usage of biodiesel fuel blends in existed diesel engine minimize pollutants, but true efficiency of the diesel engine decreases due to insufficient air fuel mixture and swirl. To improve entire air- fuel mixture, swirl and turbulence characteristics needs to modification in combustion chamber shape and nozzle geometry. Now a day's most of modern diesel engine running with CRDI mode due to meeting engine norms. The Biodiesel fuel is convenient to use in conventional diesel engine [1-3]. The present situation given, more attention on usage of sustainable energy resources instead of diesel fuel. The drawback of usage of the fossil fuel in engine is emits more pollutants and affect on living beings. Hence, it is considered globally very serious matter to control emissions. All countries migrate to usage of alternative renewable sources in existed diesel engine [4]. The performance of bio fuelled diesel engine exhibits similar performance as diesel engine [5]. The research works carried with various fuel combinations in diesel engine. The experts conducted experiments with various injection strategies in diesel engine [6, 7]. The Transesterification process is one of very common method to reduce viscosity of biodiesel [8]. The biodiesel derived from transesterification method is 
suitable for I.C engine application to reduce emission and improve engine output. The investigators worked on the diesel engines reported that efficiency of diesel engine is higher than the bio fuelled diesel engine [9-11]. The diesel engine powered with rice brain biodiesel showed better BTE, minimum brake specific fuel consumption (BSFC), reduced $27.47 \%$ of smoke, $\mathrm{CO}$ and UBHC emissions [12]. The diesel engine has declined in its BTE with higher blend ratio [13]. The harmful pollutants like $\mathrm{CO}$, smoke and $\mathrm{HC}$ were minimized by addition of desulfurized tyre oils in diesel fuel (DF) [14]. The engine powered with jathropa oil methyl ester (JOME) and its blends found that slightly lower BTE and reduced emissions as compared to DF [15].

Many research works carried out on diesel engine by using several biodiesel fuels with different injection strategies. The combustion characteristics are affecting by advancement or retardation of fuel IT. The cylinder pressure and temperature are affected by retarded fuel IT in diesel engine [16]. The diesel engine powered waste cooking oil fuel found that better BTE and reduced pollutants at $40^{\circ}$ BTDC fuel [17]. The biodiesel operated diesel engine performance improved by combined effect of IOP and retarded fuel IT [18]. The diesel engine operated with combination of JOME and tyre pyrolysis blend showed that reduced $\mathrm{CO}, \mathrm{PM}$ and UBHC emissions by $14.2 \%, 13.26 \%$ and $9.3 \%$ respectively at $24.5^{\circ} \mathrm{CA}$ BTDC [19]. The performance of engine enhanced for varieties fuel combinations with increasing in IOP [20]. The diesel engine with biodiesel blends found better torque and reduced BSFC at advancing the fuel IT [21].

The nozzle holes geometry is one of the important parameter considered in engine to alter the performance, combustion and emission characteristics of engine. Ten holes nozzle geometry gave best performance in engine at full load condition [22]. The number of holes variation in nozzle injector leads to better performance of engine and reduced emissions [23]. The biodiesel powered diesel engine improved performance and reduced emissions by altering injection strategies [24]. The diesel engine operated with honge oil methyl ester (HOME), hone oil methyl ester (HnOME) and cotton oil methyl ester (COME) biodiesel fuels given better performance and lower emissions at retarded IT of $19^{\circ} \mathrm{BTDC}$, IOP 230 bar and 4 holes nozzle injector [25].

The modification of combustion chamber shapes with suitable injection strategies are both required to enhance swirl, tumble turbulence and squish characteristics in combustion chamber shape. Hence, modification of both combustion chamber shape and nozzle geometry leads to improve performance of the engine. The toroidal combustion ((TCC) shape with Pongamia BDF exhibits better BTE than baseline hemispherical combustion chamber (HCC) shape in the diesel engine [26]. The combine effect of TRCC shape and higher IOP with Pongamia BDF leads to improved BTE and reduced emissions in diesel engine [27]. The diesel engine powered with BDF and TRCC shape performed better performance and reduced emissions as compared to cylindrical, trapezoidal shapes [28]. The combined effect of cylindrical shape with 5 holes nozzle geometry reduced NOx emissions up to $45 \%$ and slightly reduced BTE of the engine was observed as compared to a standard shape [29]. The diesel engine with pongamia oil methyl ester B40 blend reported higher BTE in baseline shape, but reduced emissions in TCC shape [30]. The engine performance of diesel engine remains same but emissions were reduced by modification of combustion shape [31]. The diesel engine operated with TRCC shape reported better BTE, minimum SFC and reduced pollutants at retarded fuel IT [32]. The HOME -producer operated diesel engine performed better BTE and reduced pollutants for TRCC shape, higher IOP and 4 holes nozzle injector [33]. The diesel engine powered with $20 \%$ of JOME fuel found higher efficiency and lower pollutants for TCC shape [34]. The diesel engine found higher BTE and reduced harmful pollutants for TRCC shape, 200 bar IOP and $25^{\circ}$ BTDC [35]. The experimental results in diesel engine found that fuel IT of $27^{\circ}$ BTDC, IOP of 240 bars, 5 holes nozzle geometry and TRCC shape are most favorable for better BTE with nominal emissions (36).

Now days, modern biodiesel fuelled diesel engine operates with CRDI mode to reduce emissions and improve the performance of the engine. Hence, most of the research works turning towards biodiesel powered CRDI diesel engine. The CRDI diesel engine operated with Simarouba biodiesel blend B30 yielded best performance with nominal emissions at 800 bar and $13^{\circ}$ BTDC [37]. The performance of CRDI diesel engine improved with tung oil diesel ethanol blends, but slightly increased in NOx emission [38]. The CRDI diesel engine operated with mahua methyl ester blend gave better combustion performance and reduced UBHC, CO and smoke emissions at 880 bar IOP [39]. The CRDI diesel engine operated with BDF and TRCC shape gave better performance and reduced smoke \& $\mathrm{NO}_{\mathrm{x}}$ emissions under injection strategies of 7 holes injector, 900 bar IOP and $10^{\circ}$ BTDC [40]. The diesel engine run with CRDI mode gave the reduced $\mathrm{CO}, \mathrm{UBHC}$ and smoke emissions except $\mathrm{CO}_{2}$ and NOx, [41]. The CRDI diesel engine showed that lower opacity for advanced combustion mode as compared to conventional C.I engine [42]. The BTE of CRDI diesel engine decreases up to $30 \%$ of plastic oil blend, but $\mathrm{CO}_{2}$ and $\mathrm{NO}_{\mathrm{x}}$ emissions are decreases as increasing in blend [43]. The modified CRDI diesel engine operated with 20\%karanja biodiesel blend gave higher BTE with reduced emissions [44]. The CRDI BDF diesel engine found that reduced particulate matter size of exhaust at higher IOP and retarded IT [45]. The CRDI diesel engine operated with diesel-tung oil-ethanol blended fuels gave longer ID, higher PP, higher HRR and shorter CD as compare to diesel fuel for different injection strategies [46]. The CRDI diesel engine operated with karanja biodiesel blends gave higher BTE than mineral diesel fuel at start of pilot injections $-21^{\circ} \mathrm{CA}$ and 1000 bar IOP [47]. CRDI engine experiment results showed that engine performance improved up to $75 \%$ swine lard methyl esters blend [48].

By the exhaust literature survey, it is observed that suitable modifications are adopted for biodiesel operated diesel 
engine to achieve higher efficiency and lower emissions which are reported in literature review [32-34]. In view of above statement, the minimum research work carried with modified combustion chamber shape, injection nozzle geometry and MIS in CRDI mode diesel engine operated with POME biodiesel fuel. Hence, in our current experimental work carried on modified CRDI diesel engine with MIS operated with POME as a biodiesel fuel. The objective of our research work is to optimization of MIS in modified CRDI diesel engine to achieve higher BTE with less emission to meet EURO emission standards.

\section{Materials Method}

\subsection{Palm Oil Methyl Ester Properties}

Palm-biodiesel is most promisable alternative fuel for C.I. engine application and most suitable source for biodiesel production [49]. If Palm oil come out from the mesocarp or flesh of the oil palm fruit used as edible oil, while palm kernel oil comes out from the kernel or seed used as non edible oil. The edible palm oil is about 49 percent saturated fat, while non edible palm oil is about 81 percent saturated fats, respectively. The palm oil can be produced mainly countries like Indonesia, Malaysia, Nigeria, Thialand, and Colombia etc. The non edible palm oils split by hydrolysis yields fatty acids with glycerin as a byproduct. The biodiesel can be derived from kernel of palm oil with help of transesterifcation process. In our experiment POME biodiesel fuel extracted from tranesterification process using biodiesel plant. The list of important properties of POME is enumerated in the below Table 1. However, POME showing higher viscosity than mineral diesel was observed.

Table 1. Properties of POME.

\begin{tabular}{lll}
\hline Properties & Diesel & POME \\
\hline Density $\left(\mathrm{kg} / \mathrm{m}^{3}\right)$ & 840 & 880 \\
Energy density $(\mathrm{kJ} / \mathrm{kg})$ & 43,000 & 38,400 \\
Viscosity at $40^{\circ} \mathrm{C}(\mathrm{cSt})$ & $2-5$ & 3.94 \\
Flash Point $\left({ }^{\circ} \mathrm{C}\right)$ & 75 & 160 \\
Cetane Number & $45-55$ & --- \\
Carbon Residue $(\%)$ & 0.1 & --- \\
Pour point $\left({ }^{\circ} \mathrm{C}\right)$ & -5 & --- \\
\hline
\end{tabular}

\subsection{Experimental Setup and Methodology}

The experimental setup has showed in below Figure 1. The main specifications of engine are enumerated in the Table 2. The engine cooling was maintained by circulating the water. A piezoelectric transducer (Make: PCB Piezotronics, Model: HSM 111A22, Resolution: $0.145 \mathrm{mV} / \mathrm{kPa}$ ) was utilized for measurement of inline cylinder pressure. The hartridge smoke meter and five-gas analyzers (A DELTA 1600 S-nondispersive infrared analyzer) are utilized to measure smoke opacity and emissions respectively under steady state condition of engine. The engine rpm is maintained at 1500 rpm with adjusting flow rate of pump. As per investigators evidence about modifications of CRDI biodiesel fueled diesel engine is required to improve performance and reduce emissions [ $40 \& 42]$. The $40 \%$ emissions can be reduced and improvement of combustion characteristics by MIS [51]. The main modification in our research engine enumerated here step by step is as follows. The CRDI mode system has developed in house and controlled by electronic control unit (ECU) facility. The ECU system is one of electronic facility attached to CRDI biodiesel fuelled diesel engine and is control the fuel injection, timing and oxygen quantity etc, with help of sensors. The high pressure injection facility is incorporated in the engine powered by POME as alternative fuel biodiesel. The TRCC shape is fabricated using CNC machine keeping constant compression ratio 17.5. The existed HCC shape is replaced by TRCC shape in engine. The existed 6 holes nozzle geometry replaced by 7 holes nozzle geometry. The reason to select 7 holes CRDI nozzle geometry and TRCC shape are optimized in our previous research work at $80 \%$ load. As part of research work to optimization of MIS in modified CRDI engine, we selected two combinations of multiple strategies 40-20-40 and 40-3030. The experiments are conducted on above modified set up operated with POME and diesel fuel with both MIS combinations. In the first phase of work, IT varied from $-25^{\circ}$ $\mathrm{CA}$ to $5^{\circ} \mathrm{CA}$ at constant 600 bar IOP and optimized MIS combination at constant fuel IT. In second phase of work, the IOP varied from 600 bar to 1000 bar at constant IT and optimized MIS combination at constant IOP.

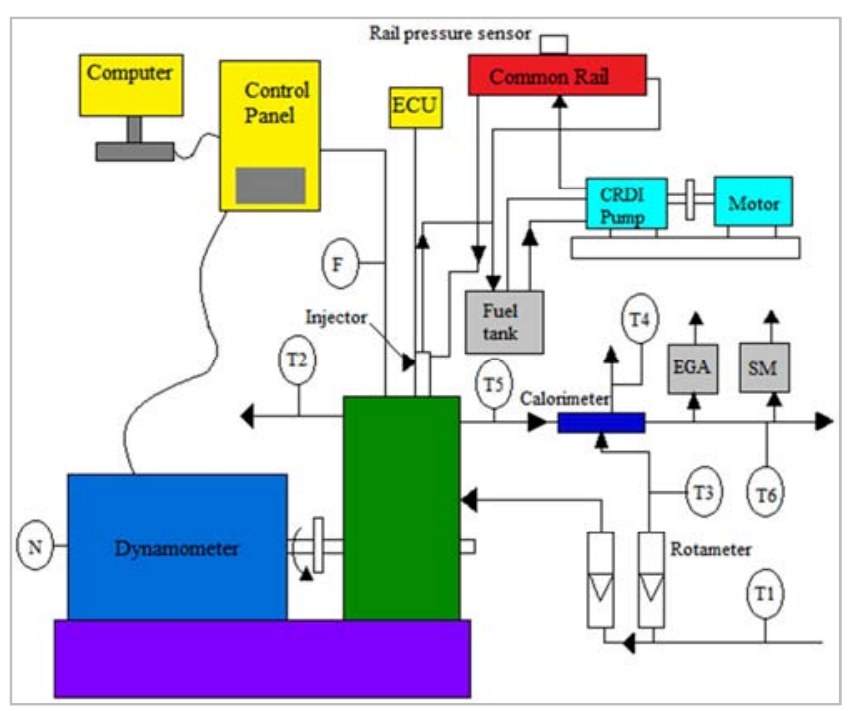

Figure 1. Schematic diagram of experimental set up of CI engine test rig with CRDI.

T1, T3 - Intake Water Temperature. T2 - Outlet Engine Jacket Water Temperature. T4 - Outlet Calorimeter Water Temperature T5 - Exhaust Gas Temperature before Calorimeter T6 - Exhaust Gas Temperature after Calorimeter F1- Fuel Flow DP (Differential Pressure) unit. N - RPM encoder, EGA - Exhaust Gas Analyzer, SM - Smoke meter.

Table 2. Specifications of the CI engine.

\begin{tabular}{ll}
\hline Parameter & Specification \\
\hline Type & TV 1 (Kirlosker) \\
Software used & Engine soft \\
Nozzle opening pressure & $220-225$ bar \\
Governor type & Mechanical centrifugal type \\
\hline
\end{tabular}




\begin{tabular}{ll}
\hline Parameter & Specification \\
\hline Number of cylinder & Single cylinder \\
Number of stroke & Four stroke \\
Fuel & H.S. Diesel \\
Rated power & $5.2 \mathrm{~kW}(7 \mathrm{HP}$ at $1500 \mathrm{rpm})$ \\
Bore & $0.0875 \mathrm{~m}$ \\
Stroke length & $0.11 \mathrm{~m}$ \\
Compression ratio & $17.5: 1$ \\
Air Measurement Manometer & \\
Made & MX201 \\
Type & U-type \\
Range & $100-0-100 \mathrm{~mm}$ \\
Eddy current Dynamometer & \\
Model & AG-10 \\
Type & Eddy current \\
Maximum & $7.5 \mathrm{~kW}$ (at $1500-3000 \mathrm{RPM})$ \\
Flow & Water must flow through the \\
Dynamometer arm length & dynamometer during the use \\
Fuel measurement unit- range & $0.180 \mathrm{~m}$ \\
\hline
\end{tabular}

\subsection{Uncertainty Analysis}

The uncertainties parameter are mainly considered due to errors in measurements, hence these parameters are essentially to consider during calculation. The list of uncertainties variable are given in the Table 3 .

Table 3. The uncertainties in the calculated parameters.

\begin{tabular}{ll}
\hline Measure variable & Accuracy $( \pm)$ \\
\hline Load & 0.1 \\
Engine speed $(\mathrm{rpm})$ & 1 \\
Temperature $\left({ }^{\circ} \mathrm{C}\right)$ & 1 \\
Fuel consumption $(\mathrm{g})$ & 0.1 \\
Measured variable & Uncertainty $(\%)$ \\
$\mathrm{HC}$ & \pm 1.2 \\
$\mathrm{CO}$ & \pm 2.5 \\
$\mathrm{NO}$ & \pm 2.3 \\
$\mathrm{Smoke}$ & \pm 2.0 \\
$\mathrm{Calculated}$ parameter & Uncertainty $(\%)$ \\
$\mathrm{BTE}(\%)$ & \pm 1.2 \\
$\mathrm{HRR}\left(\mathrm{J} /{ }^{\circ} \mathrm{CA}\right)$ & \pm 1.3 \\
\hline
\end{tabular}

\section{Results and Discussion}

The experiments are conducted on modified CRDI diesel engine operated with the diesel and POME fuels with two MIS combinations. The performance, combustion and emission characteristics are discussed at $80 \%$ load.

\subsection{The Optimization of Injection Timing for Multiple Injection Strategy}

\subsubsection{Effect of BTE with IT on Multiple Injection Strategy}

The figure 2 showed that effect of IT on BTE for MIS and SIS for both POME and diesel fuels in modified CRDI engine. The maximum BTE has obtained at $10^{\circ}$ BTDC for both fuels and all injection strategies. The maximum BTE obtained at $10^{\circ}$ BTDC in modified CRDI diesel engine [40]. This could due to better atomization, enhanced air fuel mixing quality at 600 bar and reduce wall wetting leads to better burning of fuel. The BTE of modified CRDI engine is decreased by advancement or retardation of fuel due to wall impingement effect. The similar results supported by Avinash Kumar Agarwal et al. [44]. The Pilot injection gave higher thermal efficiency of CRDI biodiesel fuelled engine [47]. However, early injection of pilot injection may leads to higher fuel consumption due to lean mixture formation. This is leads to lower engine performance, but in turn late injection leads to better performance of engine due to active fuel burning involved in presence of oxidation. Hence, MIS is chosen in modified CRDI diesel engine to enhance performance of engine. However, diesel showed higher BTE than POME fuel due to higher calorific value. The POME fuel results for 40-20-40 MIS combination are $27.5 \%, 28 \%$, $28.5 \%, 30.25 \%, 29.75 \%, 29.25 \%, 28.75 \%$ for $-25^{\circ},-20^{\circ},-15^{\circ}$, $-10^{\circ},-5^{\circ}, 0^{\circ}, 5^{\circ} \mathrm{CA}$ respectively. Similarly, for $40-30-30$ are $27 \%, 27.5 \%, 28 \%, 29.75 \%, 29.25 \%, 28.75 \%, 28 \%$ for $-25^{\circ}$, $20^{\circ},-15^{\circ},-10^{\circ},-5^{\circ}, 0^{\circ}, 5^{\circ} \mathrm{CA}$ respectively. However, 40-20-40 MIS gave $2 \%$ higher BTE than $40-30-30$ MIS and SIS at $-10^{\circ}$ BTDC in modified CRDI diesel engine.

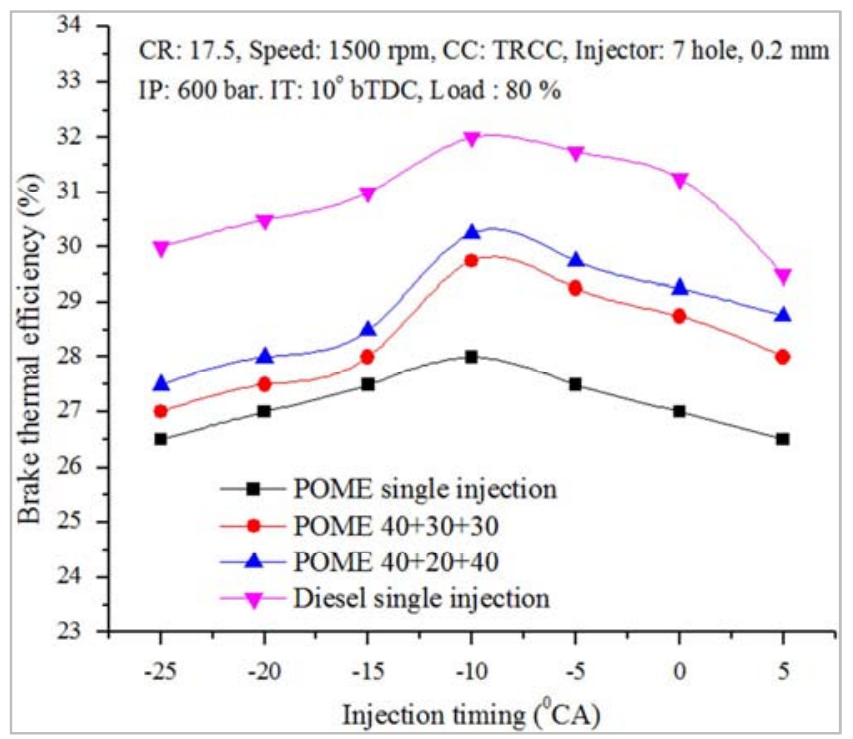

Figure 2. Variation of BTE with IT for multiple and single injection strategies.

\subsubsection{Effect of Combustion Characteristics with IT on Multiple Injection Strategy}

The figures 3, 4, 5 and 6 are illustrates that variation combustion characteristics ID, CD, PP and HRR with the IT in modified CRDI diesel engine at 600 bar. It observed that higher ID and CD for all IT's of POME as compared to DF. The ID and $\mathrm{CD}$ are decreasing trend up to $-10^{\circ} \mathrm{BTDC}$, later increasing trend was observed. This could be due to higher exhaust gas temperature at retarded IT fuel. The both PP and HRR are lower for POME as compared with DF. This is due to presence of lower calorific value of POME fuel. In addition to, PP and HRR are found to be higher at advanced fuel IT due to longer ID. Also more amount fuel available during premixed combustion phase could be the reason to enhanced PP and HRR. The similar results are observed by Roy M. M. [16]. However, ID results of POME fuel are $15.6,14.82,14.2,13.5,13.9,14.01,14.67^{\circ} \mathrm{CA}$ for $-25^{\circ},-20^{\circ},-15^{\circ},-10^{\circ},-5^{\circ}, 0^{\circ}, 5^{\circ}$ CA respectively for $40-20-40$ MIS combination. Similarly, for 40-30-30 MIS combination 
results are $15.8,15.21,14.3,13.9,14.01,14.21,15.01^{\circ} \mathrm{CA}$ for $25^{\circ},-20^{\circ},-15^{\circ},-10^{\circ},-5^{\circ}, 0^{\circ}, 5^{\circ} \mathrm{CA}$ respectively. The results of $\mathrm{CD}$ in engine operated with 40-20-40 MIS combination of POME fuel are $36,35,32,29,29,31,33^{\circ} \mathrm{CA}$ for $-25^{\circ},-20^{\circ}$, $15^{\circ},-10^{\circ},-5^{\circ}, 0^{\circ}, 5^{\circ} \mathrm{CA}$ respectively. Similarly, for $40-30-30$ MIS combination results are $38,36,33,30,32,33,34^{\circ} \mathrm{CA}$ for $25^{\circ},-20^{\circ},-15^{\circ},-10^{\circ},-5^{\circ}, 0^{\circ}, 5^{\circ} \mathrm{CA}$ respectively The $40-20-40$ MIS combination of POME has showed lower ID and CD as compared to other combination at $-10^{\circ}$ BTDC. However, results of PP with POME operated 40-20-40 MIS combination are 87, $83,79,73,69,63,60$ bar for $-25^{\circ},-20^{\circ},-15^{\circ},-10^{\circ},-5^{\circ}, 0^{\circ}, 5^{\circ} \mathrm{CA}$ respectively. Similarly, for 40-30-30 MIS are 86, 82, 78, 72.5, $68.5,62,59$ bar for $-25^{\circ},-20^{\circ},-15^{\circ},-10^{\circ},-5^{\circ}, 0^{\circ}, 5^{\circ} \mathrm{CA}$ respectively. The results of HRR 40-20-40 MIS are 98, 87, 80, $68,65,62,58 \mathrm{~J} /{ }^{\circ} \mathrm{CA}$ for $-25^{\circ},-20^{\circ},-15^{\circ},-10^{\circ},-5^{\circ}, 0^{\circ}, 5^{\circ} \mathrm{CA}$ respectively. Similarly, for 40-30-30 MIS are 96, 86, 78, 66, 63, $60,56 \mathrm{~J} /{ }^{\circ} \mathrm{CA}$ for $-25^{\circ},-20^{\circ},-15^{\circ},-10^{\circ},-5^{\circ}, 0^{\circ}, 5^{\circ} \mathrm{CA}$ respectively. The 40-20-40 MIS combination of POME showed higher PP and HRR at $-10^{\circ}$ BTDC and crank angle 359 degree in modified CRDI diesel engine.

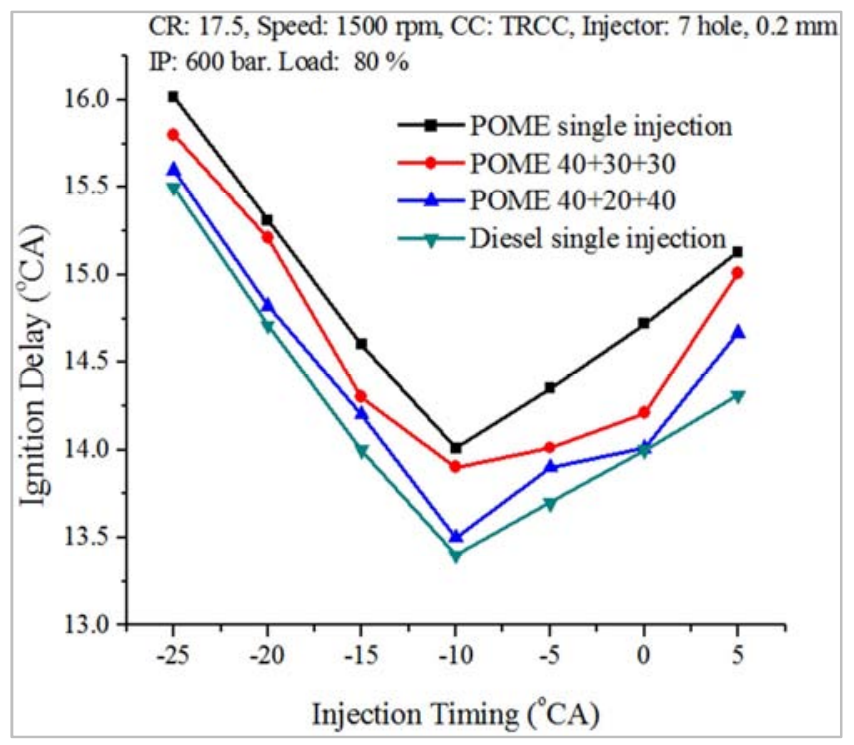

Figure 3. Variation of ID with IT for multiple and single injection strategies.

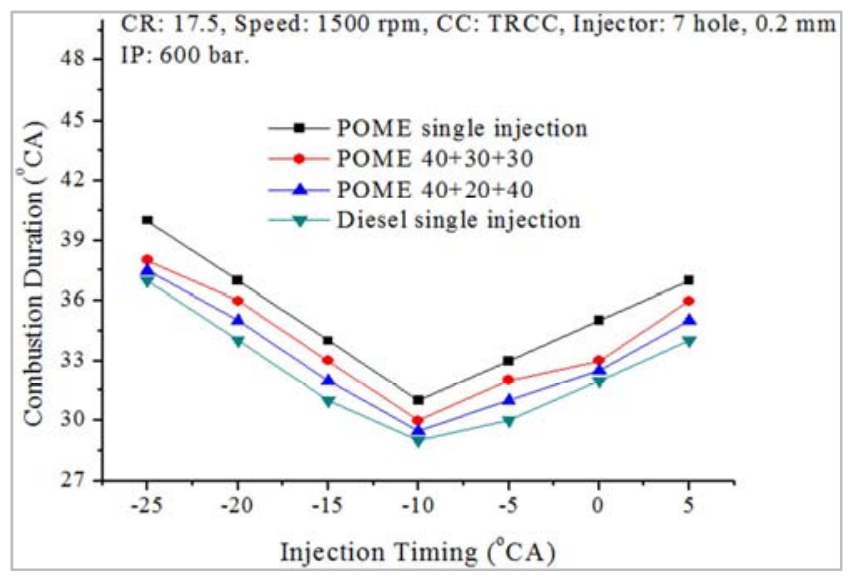

Figure 4. Variation of $C D$ with IT for multiple and single injection strategies.

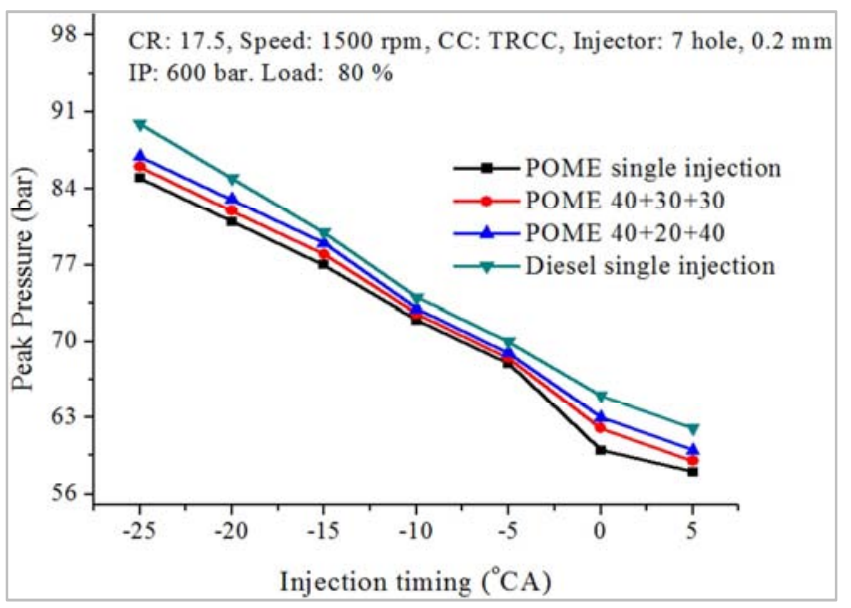

Figure 5. Variation of PP with IT for multiple and single injection strategies.

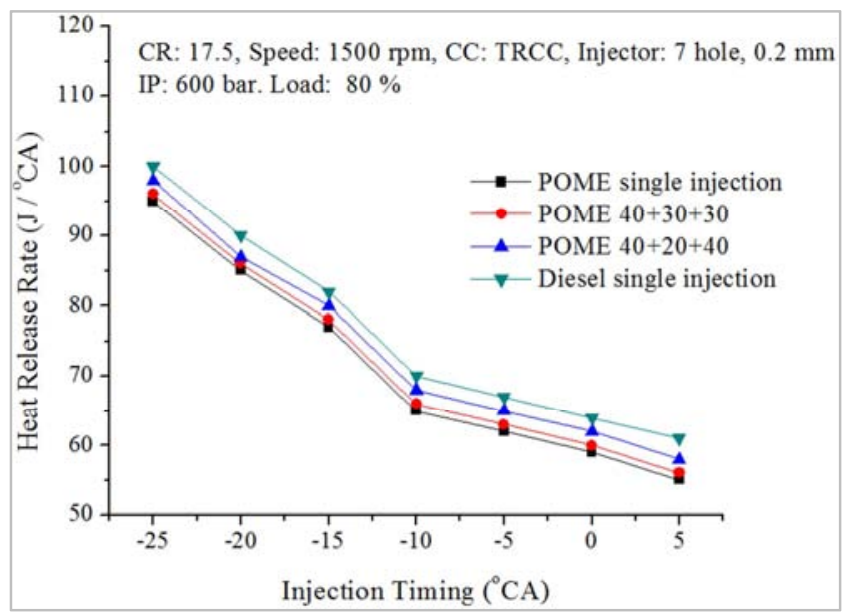

Figure 6. Variation of HRR with IT for multiple and single injection strategies.

\subsubsection{Effect of Smoke Level with IT on Multiple Injection Strategy}

From figure 7 depicts that effect of IT on smoke level at $80 \%$ load. The diesel fuel operated showed minimum smoke level than POME operated engine due to free fatty acid (FFA) present in POME fuel leads to reduce the quality of mixing strength. This could be attributed that smoke level was deceases up to $-10^{\circ}$ BTDC due to reduced wall wetting and better combustion. But beyond $-10^{\circ}$ BTDC smoke level was increasing trend due to sluggish diffusion combustion phase leads to reduce mixing strength for all fuels and injection strategy. The results of smoke POME operated fuel for 40-20-40 MIS are 50, 47, 45, 43, 45, 48, $51 \mathrm{HSU}$ for $-25^{\circ},-20^{\circ},-15^{\circ},-10^{\circ},-5^{\circ}, 0^{\circ}, 5^{\circ} \mathrm{CA}$ respectively. Similarly, for 40-30-30 MIS are 52, 49, 47, 45, 47, 50, 53 HSU for $-25^{\circ},-20^{\circ},-15^{\circ},-10^{\circ},-5^{\circ}, 0^{\circ}, 5^{\circ} \mathrm{CA}$ respectively. The particulate matter reduced by MIS in CRDI engine [51]. The 40-20-40 MIS combination of POME fuel gave lower smoke level as compared to 40-30-30 combination in CRDI engine. The MIS has reduced smoke opacity due to unburned during previous injection leads to burn remaining particulate matter and ensured complete combustion. The MIS exhibits more quantity of air utilization in the 
combustion process due to different injection timing of fuel. Because of more utilization of air leads to continuation of combustion in later also, hence reduced smoke level was observed for MIS. The smoke level was reduced by $4 \%$ for 40-20-40 than other strategy at $-10^{\circ}$ BTDC in modified CRDI diesel engine.

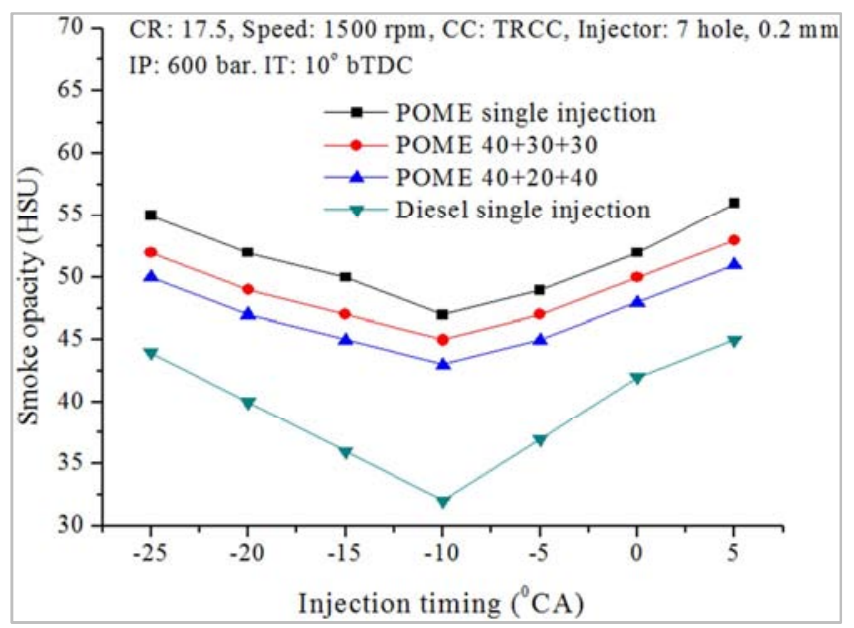

Figure 7. Variation of smoke opacity with IT for multiple and single injection strategies.

\subsubsection{Effect of CO and HC Emissions with IT on Multiple Injection Strategy}

From the figure 8 and 9 revealed that variation of $\mathrm{HC}$ and $\mathrm{CO}$ emissions with fuel IT's at $80 \%$ load. The lower CO and $\mathrm{HC}$ emissions are formed at $-10^{\circ}$ BTDC for all fuels and injection strategies. This could be attributed that proper combustion process at this fuel at 600 bar and obtained higher BTE at same condition of engine. The Similar results observed by Atul Dhar et al. (47). The combustion chamber wall wetting was occurred at advanced fuel IT and more fuel entering in to crevices of combustion chamber at retarded fuel IT. Hence, more $\mathrm{CO}$ and $\mathrm{HC}$ emissions are occurred for other fuel IT's. These both emissions are higher for POME operation than mineral diesel. This could be attributed that presence of higher viscosity in POME fuel leads to bigger size of droplet at same IOP. The oxygen contains in-between $1.80 \%-2.37 \%$ to reduce emissions, when blends used in diesel engine [53]. But in our case, POME (B100) is produced higher emissions than diesel due to higher oxygen content. Hence, comparatively lower density of POME might lead to lowered combustion temperature supports to higher emissions. The results of HC emission in engine operated with 40-20-40 MIS of POME fuel are $51,48,45,42,45,47,50 \mathrm{ppm}-25^{\circ},-20^{\circ},-15^{\circ},-10^{\circ}$, $-5^{\circ}, 0^{\circ}, 5^{\circ}$ CA respectively. Similarly, for 40-30-30 MIS results are $53,50,47,44,47,49,52$ ppm for $-25^{\circ},-20^{\circ},-15^{\circ}$, $-10^{\circ},-5^{\circ}, 0^{\circ}, 5^{\circ} \mathrm{CA}$ respectively. The results of $\mathrm{CO}$ emission in engine operated with 40-20-40 MIS combination of POME fuel are $0.155,0.15,0.145,0.14$, $0.144,0.15,0.16 \%$ for $-25^{\circ},-20^{\circ},-15^{\circ},-10^{\circ},-5^{\circ}, 0^{\circ}, 5^{\circ} \mathrm{CA}$ respectively. Similarly, for $40-30-30$ MIS results are 0.165 , $0.16,0.155,0.15,0.154,0.158,0.168 \%$ for $-25^{\circ},-20^{\circ},-15^{\circ}$, $-10^{\circ},-5^{\circ}, 0^{\circ}, 5^{\circ} \mathrm{CA}$ respectively at $80 \%$ load. The MIS could be minimize the emissions with $\mathrm{CO}$ and $\mathrm{HC}$ emissions for POME operated engine due to complete combustion process in the modified CRDI diesel engineat $-10^{\circ}$ BTDC and 600 bar. Hence, 5\% $\mathrm{HC}$ emissions reduced and 7\% $\mathrm{CO}$ emissions reduced for 40-20-40 MIS.

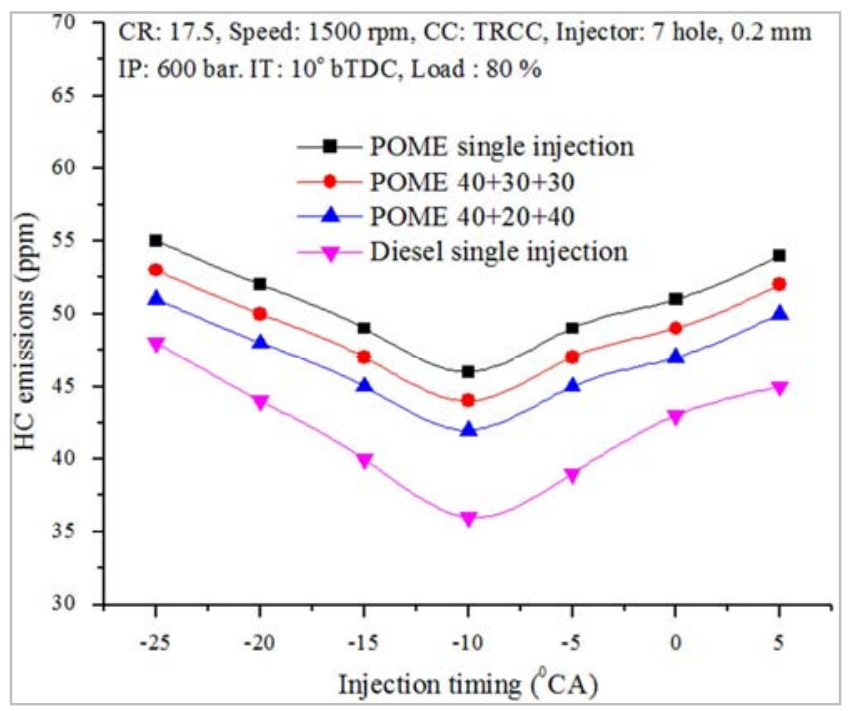

Figure 8. Variation of HC emission with IT for multiple and single injection strategies.

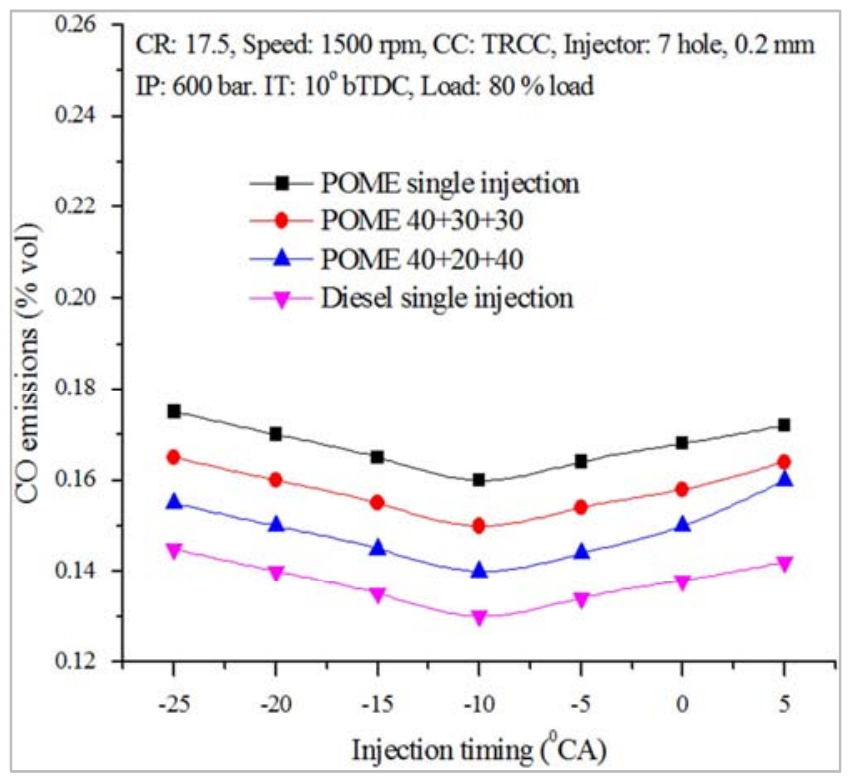

Figure 9. Variation of $\mathrm{CO}$ emission with IT for multiple and single injection strategies.

\subsubsection{Effect of $\mathrm{NO}_{x}$ Emissions with IT on Multiple Injection Strategy}

Figure 10 illustrate those variation $\mathrm{NO}_{\mathrm{x}}$ emissions on fuel IT's in modified CRDI diesel engine. The well known fact that increased in $\mathrm{NO}_{\mathrm{x}}$ emissions at advanced IT with all fuels and injection strategies. This is due to higher PP, HRR and longer ID. Similar trend was observed by experts as karra et al., Khandal et al., and Mikulski et al. (22, 24 and 53). The $\mathrm{NO}_{\mathrm{x}}$ emissions are lower for POME fuel as compared to DF 
due to lower gas temperature and available more oxygen quantity in biodiesel fuels. This could be attributed that lower cetane number for biodiesel fuel as compared to DF. The MIS found minimized $\mathrm{NO}_{\mathrm{x}}$ emissions as compared to SIS due to availability of fuel quantity is less and lower exhausts gas temperature. Therefore, net heat HRR was become lower in the cylinder. The pilot injection of fuel started fuel combustion completely leads to higher cylinder pressure and temperature formation inside the cylinder. At same time immediate fuel complete combustion takes place during main injection. This leads to higher curbs of rapid pressure enhancement during premixed combustion. Hence, noise and $\mathrm{NO}_{\mathrm{x}}$ formation can be reduced by MIS. The results of $\mathrm{NO}_{\mathrm{x}}$ emission with 40-20-40 MIS of POME fuel are790, 772, $748,726,705,684,665 \mathrm{ppm}$ for $-25^{\circ},-20^{\circ},-15^{\circ},-10^{\circ},-5^{\circ}, 0^{\circ}$, $5^{\circ} \mathrm{CA}$ respectively. Similarly, for $40-30-30$ MIS results are $784,768,744,722,699,680,661 \mathrm{ppm}$ for $-25^{\circ},-20^{\circ},-15^{\circ}$, $10^{\circ},-5^{\circ}, 0^{\circ}, 5^{\circ} \mathrm{CA}$ respectively. The $40-20-40$ MIS combination of POME has showed $0.5 \%$ higher $\mathrm{NO}_{\mathrm{x}}$ as compared to $40-30-30$ MIS combination at $10^{\circ} \mathrm{BTDC}$ due to higher BTE in engine.

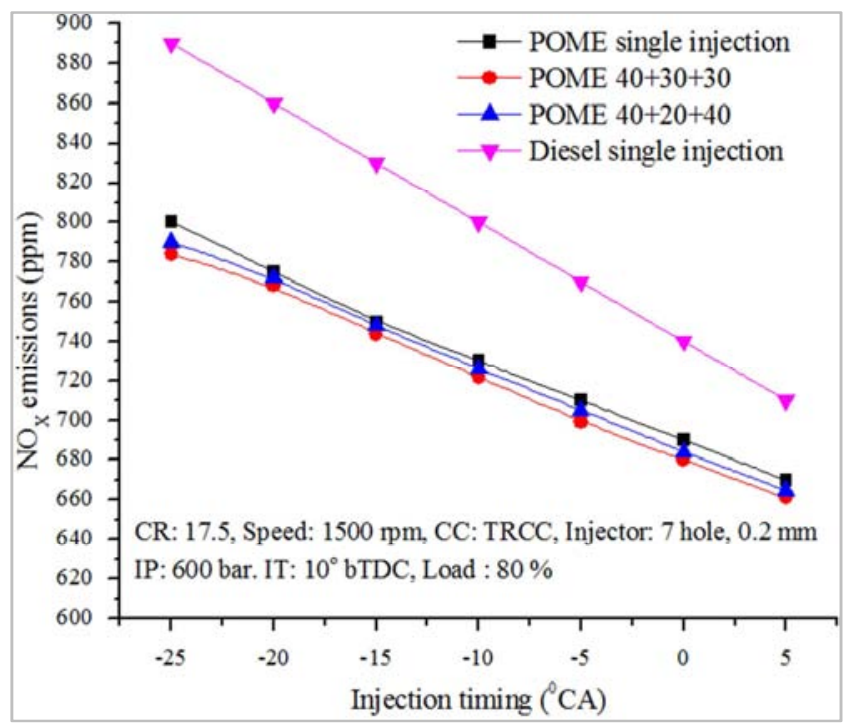

Figure 10. Variation of $N O_{x}$ emission with IT for multiple and single injection strategies.

\subsection{Optimization of Injection Pressure for Multiple Injection Strategy}

In first phase of work we have optimized for 40-20-40 MIS combination at $-10^{\circ}$ BTDC in modified CRDI diesel engine operating with POME fuel. In the second phase of work we have optimize the injection pressure with considering same MIS combinations at constant $-10^{\circ}$ BTDC and $80 \%$ load in modified CRDI diesel engine.

\subsubsection{Effect of BTE with IOP on Multiple Injection Strategy}

Figure 11 shows the effect of IOP with BTE in modified CRDI engine. The BTE of engine increases up to 900 bar for all fuel and injection strategies. This is due to improved atomization with formation of homogeneous mixture and reduced ID up to 900 bar. The similar results showed in CRDI diesel by Srinath Pai [37]. The higher fuel dispersion and penetration could be the reason to improve BTE at 900 bar IOP. The BTE of all fuel and injection strategies showed decreasing trend for 1000 bar IOP. This is due to more fuel wall wetting in crevices. The engine efficiency can enhanced by increasing IOP of fuel, hence decreased droplet size and increased droplet velocity [54]. Amongst all, diesel fuel showed higher BTE as compared to POME fuel due to lower cetane number, higher FFA present in POME fuel. The most of biodiesel fuels have potential to reach performance of diesel fuel when the moderate percentage of biodiesel blend is used [55]. The results are obtained for BTE with POME fuel operated 40-20-40 MIS combination are 29.5, 30, 30.5, $31,30.75 \%$ for $600,700,800,900,1000$ bar respectively. Similarly, for 40-30-30 MIS combination of POME operated fuel are $28.75,29.25,29.75,30.5,30 \%$ for $600,700,800$, 900,1000 bar respectively at $80 \%$ load. The $40-20-40$ MIS combination of POME showed $1.6 \%$ increased BTE as compared to other combination at 900 bar in modified CRDI diesel engine.

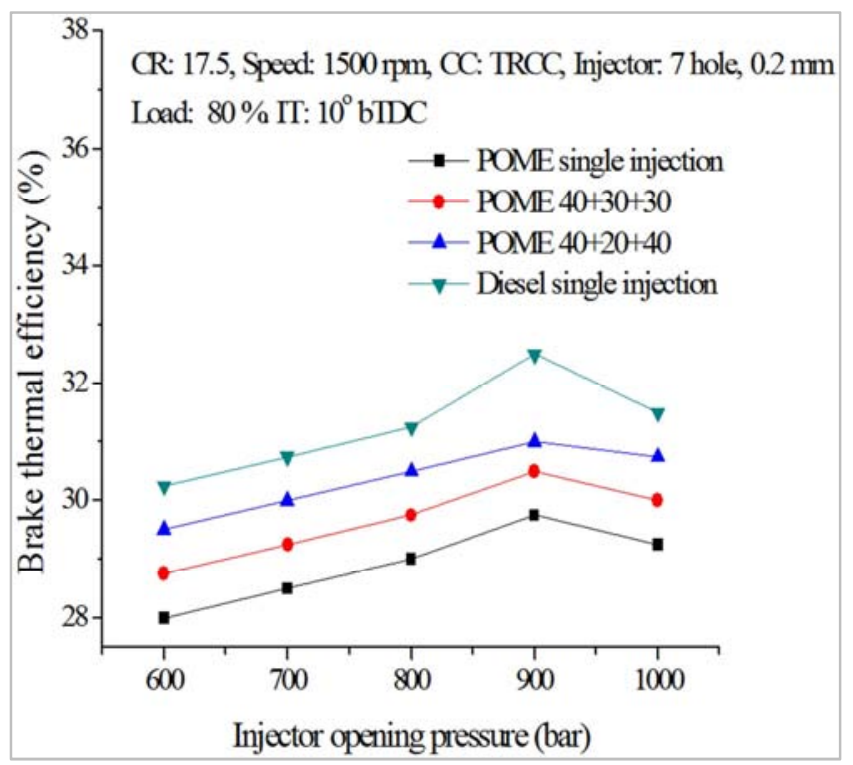

Figure 11. Variation of BTE with IOP for multiple and single injection strategies.

\subsubsection{Effect of Combustion Characteristics with IOP on Multiple Injection Strategy}

The figures $12,13,14$ and 15 were showed variations in combustion characteristics ID, CD, PP and HRR with IOP in modified CRDI engine. The both fuel temperature and pressure are most important parameters to improve the combustion characteristics [56]. The ID and CD were reduced trend by increasing the pressure due to better burning rate of fuels. But slightly increased trend was observed in both parameters beyond the 900 bar due to negating effect of performance in engine. However, the diesel fuel ensured lowest ID and $\mathrm{CD}$ as compared to POME fuel. The reason to reduce in combustion characteristics of POME fuel is due to more viscous, which 
creates the more friction around the injector needle. Hence, needle movement was slow lift leads to longer injection delay. However, MIS operated with POME fuel exhibited lower ID and CD as compared SIS. This might be due to better utilization air and better mixture formed in the combustion chamber leads to continuation of combustion of unburned fuel in end stage in power stroke of engine at higher IOP. The results of ID in engine operated with 4020-40 MIS combination of POME fuel are 13, 11.9, 10.8, $9.5,10.2{ }^{\circ} \mathrm{CA}$ for $600,700,800,900,1000$ bar respectively. Similarly, for 40-30-30 MIS are 13.4, 12.1, 10.9, 9.8, 10.5 ${ }^{\circ} \mathrm{CA}$ for $600,700,800,900,1000$ bar respectively. The results of CD for 40-20-40 MIS are 29, 28, 27, 25, $26.5^{\circ} \mathrm{CA}$ for $600,700,800,900,1000$ bar respectively. Similarly,4030-30 MIS showed 30, 29, 28, 26, 27.5 ${ }^{\circ} \mathrm{CA}$ for $600,700,800,900,1000$ bar respectively. The 40-20-40 MIS combination of POME showed 3.51\% lower ID and $4 \%$ lower $\mathrm{CD}$ as compared to other combination due to better BTE at 900 bar and $-10^{\circ}$ BTDC in modified CRDI diesel engine. If ID longer, which in turn effect on ignition parameter leads to late ignition in expansion stroke that will cause incomplete combustion process, reduced power output, and poor fuel conversion efficiency [57].

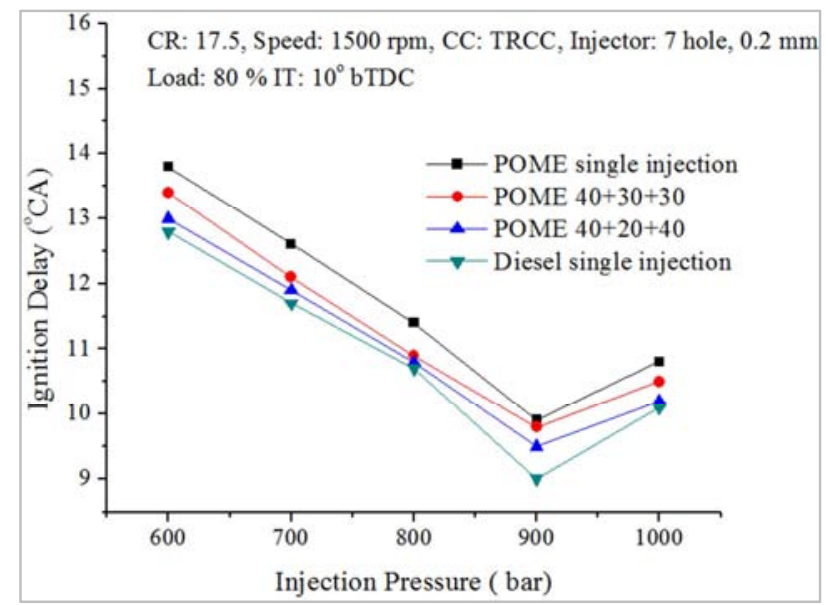

Figure 12. Variation of ID with IOP for multiple and single injection strategies.

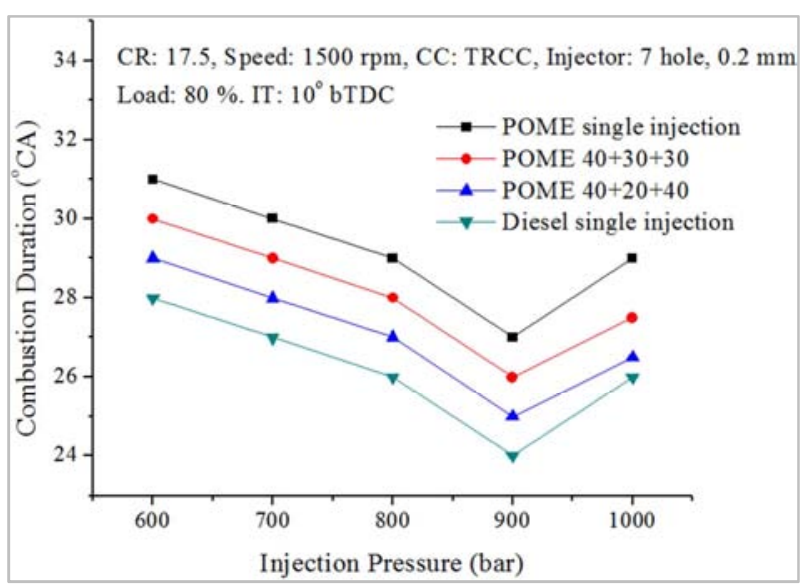

Figure 13. Variation of $C D$ with IOP for multiple and single injection strategies.

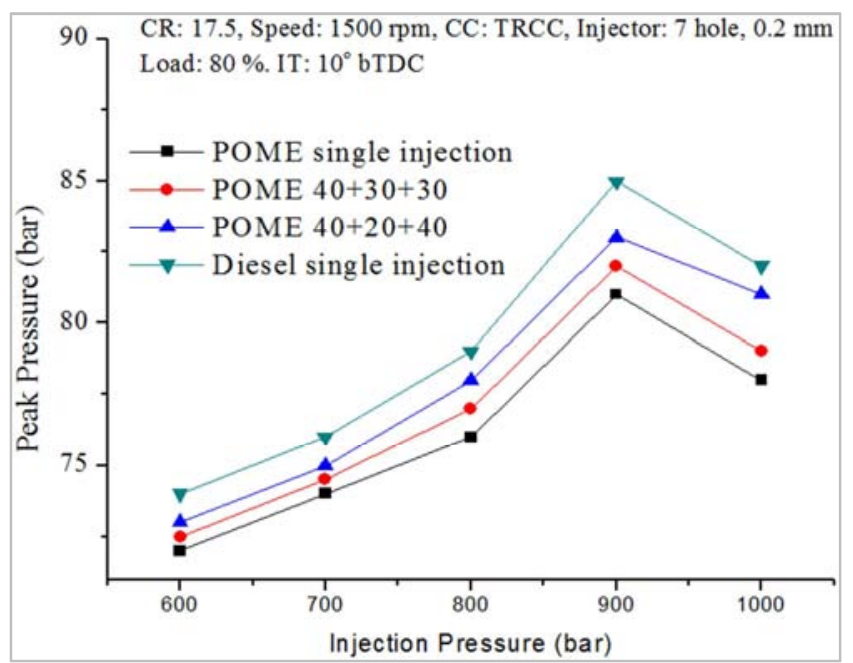

Figure 14. Variation of PP with IOP for multiple and single injection strategies.

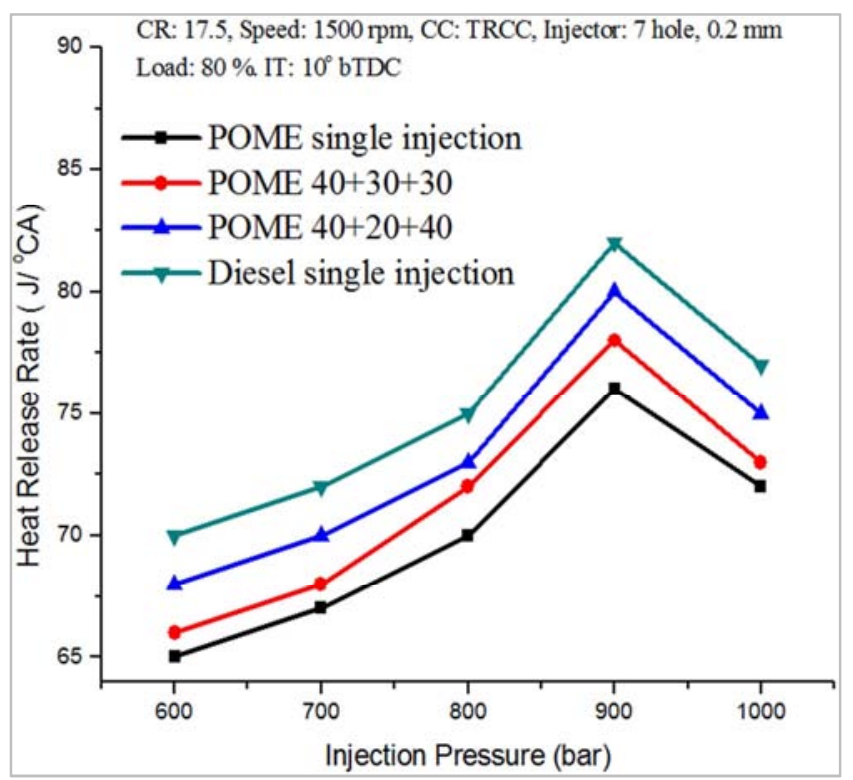

Figure 15. Variation of HRR with IOP for multiple and single injection strategies.

The both PP and HRR combustion characteristics raised trend as IOP up to 900 bar due to better atomization of fuel in combustion chamber for both fuels. The reduced droplet size of fuel enhances vaporization of fuel and easily mixes with air. It improves proper mixing of air and fuel, which leads to complete combustion. But PP and HRR reduced trend at $100 \mathrm{MPa}$ due to more amount of fuel injected from injector that occupy in the volume of crevice of engine components. However, mineral diesel was showing more PP and HRR than POME fuel. This attributed to higher energy content at 900 bar IOP in diesel fuel. But in the case of MIS of POME fuel exhibits higher PP and HRR than SIS. This is attributed that to continuation of combustion process from early stage to end stage during power stroke. The results of PP in engine operated with 40-20-40 MIS combination are $73,75,78,83,81$ bar for $600,700,800,900$, 1000 bar respectively. Similarly, for 40-30-30 MIS are 72.5, $74.5,77,82,79$ bar for $600,700,800,900,1000$ bar 
respectively. The results of HRR in engine operated with 40-2040 MIS combination of POME fuel are $68,70,73,80,74 \mathrm{~J} /{ }^{\circ}$ CA for $600,700,800,900,1000$ bar respectively. Similarly, for 40-30-30 MIS of POME operated fuel are $66,68,72,78,73 \mathrm{~J}^{/ \mathrm{o}}$ CA for $600,700,800,900,1000$ bar respectively. The 40-20-40 MIS combination of POME has showed 1.2\% higher in PP and $2.5 \%$ higher in HRR as compared to other combination at 358 degree crank angle due to better BTE in modified CRDI diesel engine. The similar results are supported by Roy M. M. [16].

\subsubsection{Effect of Smoke Opacity with IOP on Multiple Injection Strategy}

Figure 16 showed the effect of IOP on smoke level powered with POME and diesel fuels. The smoke level lower for all fuels and injection strategies at 900 bar. This is due to enhanced atomization at higher IOP resulting into completing combustion. However, mineral diesel fuel showed lower smoke emissions as compared to POME fuel. This is due to presence of heavier molecular structure in POME biodiesel leads to improper mixing strength. Mainly, MIS couple with higher IOP ensures improved air utilization leads to combustion charge particles continue their combustion process in power stroke later also. Hence, MIS showed lower smoke than SIS operated with POME. The results of smoke level in engine operated with 4020-40 combination of POME fuel are 43, 41, 38, 34, $38 \mathrm{HSU}$ for $600,700,800,900,1000$ bar respectively. Similarly, for 40-3030 combination of POME operated fuel are 45, 43, 40, 36, 40 HSU for $600,700,800,900,1000$ bar respectively. The MIS of 40-20-40 combination of POME has showed 5.5\% lower smoke intensity as compared to other combination at 900 bar in modified CRDI diesel engine. Mainly the presence of oxygen component in biodiesel helps to reduce the emission characteristics in engine [15].

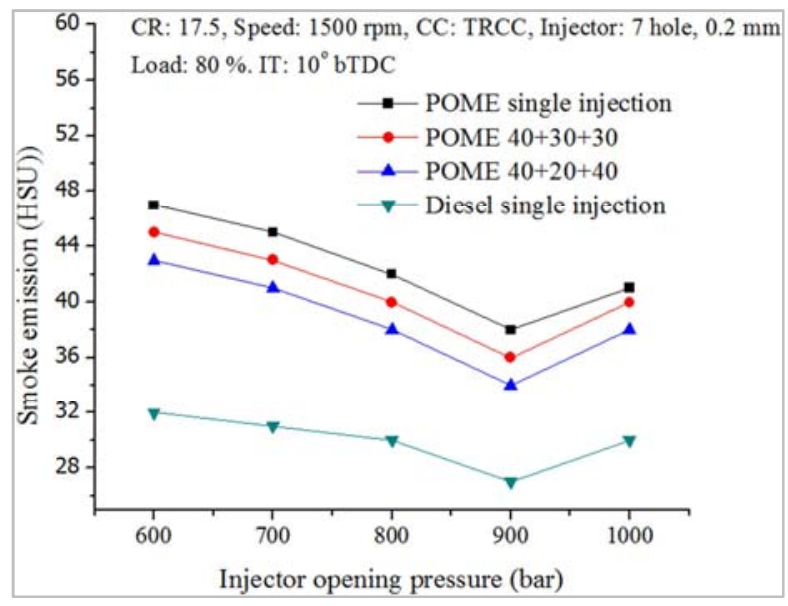

Figure 16. Variation of smoke with IOP for multiple and single injection strategies.

\subsubsection{Effect of HC, CO Emissions with IOP on Multiple Injection Strategy}

Figure 17 and 18 are showed IOP effect on both $\mathrm{HC}$ and $\mathrm{CO}$ emissions for diesel, POME. The both $\mathrm{HC}$ and $\mathrm{CO}$ emissions are decreases as increase in IOP for all injection strategies. This may be attributed that, the entire combustion process get enhanced by increase in IOP. The CO emissions may be significantly affected by cylinder temperature and enhanced IOP. However, both the emissions were minimized by enhancing injection pressure due to proper air fuel mixing in combustion chamber. This is also due to better atomization ensured stoichiometric air and fuel mixture and improved combustion at higher IOP. The association of higher $\mathrm{BTE}$ at higher IOP ensured lower $\mathrm{HC}$ and $\mathrm{CO}$ emissions for MIS than other. This may due to improved fuel consumption during combustion process at higher IOP. Hence, MIS found lower emission particle than other strategy. However, diesel was showing lower emissions as compared with other MIS combinations due to lower viscosity of DF could be the reason. The results of HC emission for 40-20-40 MIS combination of POME fuel were 42, 39, 36, 30, $37 \mathrm{ppm}$ for $600,700,800,900$, 1000 bar respectively. Similarly, for 40-30-30 combination of POME operated fuel are 44, 41, 38, 33, $39 \mathrm{ppm}$ for $600,700,800$, 900,1000 bar respectively. The results of CO emission for 40-2040 combination of POME fuel are $0.145,0.14,0.135,0.12,0.13 \%$ for $600,700,800,900,1000$ bar respectively. Similarly, for 4030-30 combination of POME operated fuel are 0.15, 0.145, 0.14, $0.125,0.135 \%$ for $600,700,800,900,1000$ bar respectively. The MIS 40-20-40 MIS combination of POME showed 10\% lower $\mathrm{HC}$ and $2.3 \%$ lower $\mathrm{CO}$ emissions as compared to other combination at 900 bar in modified CRDI diesel engine. The similar results reported by Khandal SV et al. [24].

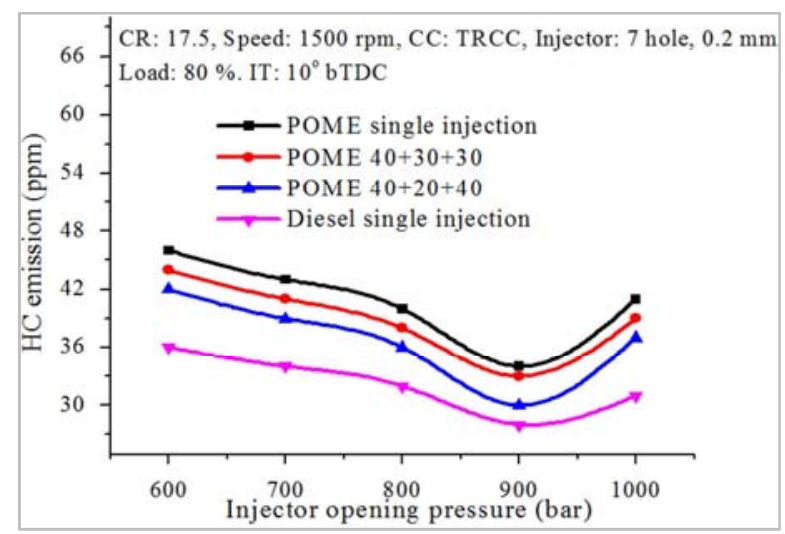

Figure 17. Variation of HC emission with IOP for multiple and single injection strategies.

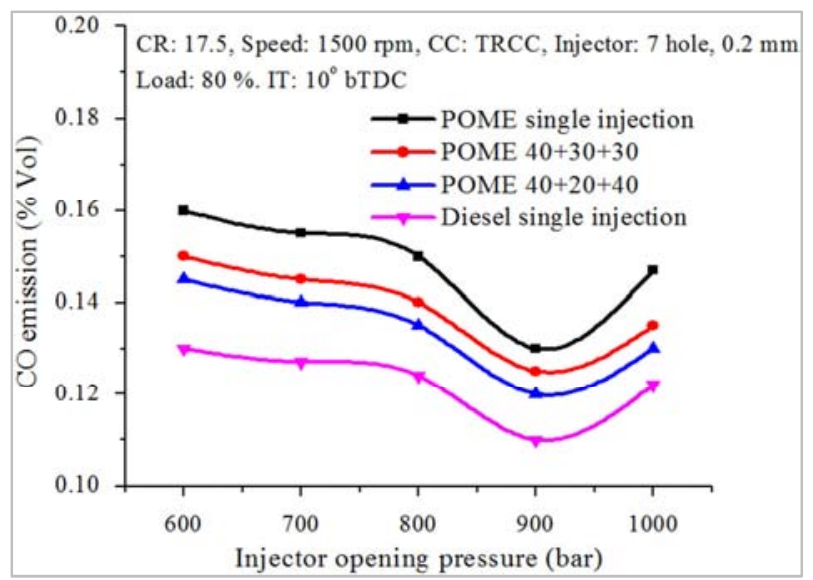

Figure 18. Variation of $\mathrm{CO}$ emission with IOP for multiple and single injection strategies. 


\subsubsection{Effect of $\mathrm{NO}_{x}$ Emissions with IOP on Multiple Injection Strategy}

The $\mathrm{NO}_{\mathrm{x}}$ emissions are formed in the combustion chamber due to presence of air during combustion at higher temperature. There are many factors affect for $\mathrm{NO}_{\mathrm{x}}$ formation like air and fuel ratio, combustion temperature and excess temperature etc. The $\mathrm{NO}_{\mathrm{x}}$ levels are increased by enhancing IOP due to speedy combustion and higher temperature during combustion cycle [39]. The figure 19 showed the variation of $\mathrm{NO}_{\mathrm{x}}$ emissions on IOP at $80 \%$ load. The higher levels of $\mathrm{NO}_{\mathrm{x}}$ are formed at IOP due to reduced fuel droplet particle size leads to improve the combustion process in combustion chamber. However, DF yielded higher $\mathrm{NO}_{\mathrm{x}}$ levels than POME fuel at 900 bar. This is due to speedy combustion of mineral diesel fuel leads to higher premixed combustion phase. The biodiesel fuel found lower energy density and higher viscosity could be the reason to reduce in $\mathrm{NO}_{\mathrm{x}}$ emissions. In case of POME fuel, $\mathrm{NO}_{\mathrm{x}}$ level improved at higher IOP due to more free oxygen atoms combined with nitrogen atoms. The $\mathrm{NO}_{\mathrm{x}}$ levels decreased trend for both MIS combination as compared to SIS due to better air utilization. The results of $\mathrm{NO}_{\mathrm{x}}$ emissions for POME operated 40-20-40 MIS combination are 722, 731, 750, $811,762 \mathrm{ppm}$ for $600,700,800,900,1000$ bar respectively. Similarly, for 40-30-30 combination of POME operated fuel are $726,735,754,825,768 \mathrm{ppm}$ for $600,700,800,900,1000$ bar respectively. The 40-20-40 MIS combination of POME showed $1.7 \%$ lower $\mathrm{NO}_{\mathrm{x}}$ emissions as compared to other combination in modified CRDI diesel engine due to better air utilization. The $40 \%$ emissions can be reduced and improvement of combustion characteristics by MIS [51].

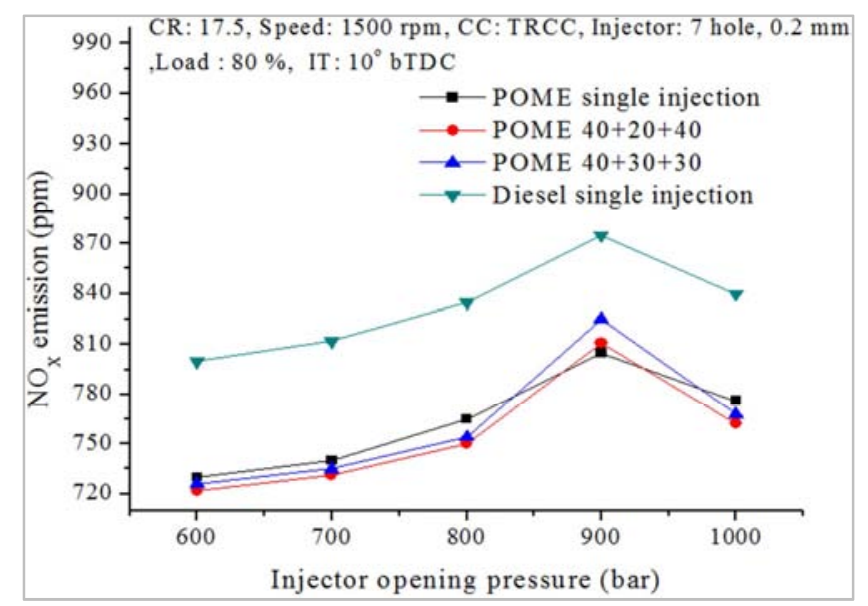

Figure 19. Variation of $N O_{x}$ emission with IOP for multiple and single injection strategies.

\subsection{Results of Comparisons Between 600 bar IOP and 900 Bar IOP for Multiple Injection Strategies}

From the below Table 4 showed that, POME operated MIS of 40-20-40 gave improved in performance and combustion characteristics and reduced emissions characteristics except $\mathrm{NO}_{\mathrm{x}}$ emission at 900 bar and $10^{\circ} \mathrm{BTDC}$ fuel IT.

Table 4. Comparison of multiple injection strategy between 600 bar IOP and 900 bar IOP at $-10^{\circ}$ BTDC.

\begin{tabular}{|c|c|c|c|}
\hline Engine Parameters & $\begin{array}{l}\text { Results for } 40-20-40 \text { combination } \\
\text { at } 600 \text { bar and } 10^{\circ} \text { BTDC }\end{array}$ & $\begin{array}{l}\text { Results for } 40-20-40 \text { combination at } 900 \\
\text { bar and } 10^{\circ} \text { BTDC }\end{array}$ & $\begin{array}{l}\text { Percentage of increase or decrease in } \\
\text { engine parameters }\end{array}$ \\
\hline BTE $(\%)$ & 30.25 & 31 & $2.47 \%$ increase in BTE \\
\hline smoke level (HSU) & 43 & 34 & $20.93 \%$ decrease in Smoke \\
\hline $\mathrm{CO}(\%)$ & 0.14 & 0.12 & $14.28 \%$ decrease in $\mathrm{CO}$ \\
\hline $\mathrm{HC}(\mathrm{ppm})$ & 42 & 30 & $19.04 \%$ decrease in $\mathrm{HC}$ \\
\hline $\mathrm{NO}_{\mathrm{x}}(\mathrm{ppm})$ & 726 & 811 & $11.70 \%$ increase in $\mathrm{NO}_{\mathrm{x}}$ \\
\hline ID $\left({ }^{\circ} \mathrm{CA}\right)$ & 13.5 & 9.5 & $29.62 \%$ decrease in ID \\
\hline PP (bar) & 73 & 83 & $13.69 \%$ increase in $\mathrm{PP}$ \\
\hline $\operatorname{HRR}\left(\mathrm{J} /{ }^{\circ} \mathrm{CA}\right)$ & 68 & 80 & $17.64 \%$ increase in HRR \\
\hline
\end{tabular}

\section{Conclusions}

From the exhaustive experimental research work carried with POME and diesel fuels powered in modified CRDI diesel engine the following conclusions enumerated at $80 \%$ load:

In the first phase of work, the POME operated MIS of 4020-40 gave slightly improved in performance and combustion characteristics and reduced emission characteristics except $\mathrm{NO}_{\mathrm{x}}$ emission as compared to SIS at $10^{\circ}$ BTDC and 600 bar in modified CRDI diesel engine.

In the second phase of work, the POME operated MIS of 40-20-40 gave percentage of increase in BTE by $2.47 \%$, PP by $13.69 \%$, HRR by $17.64 \%, \mathrm{NO}_{\mathrm{x}}$ by $11.70 \%$ and percentage of decreased in ID by $29.62 \%$, CD by $13.79 \%$, HC by $19.04 \%$, CO by $14.28 \%$, smoke level by $20.93 \%$ at $10^{\circ} \mathrm{BTDC}$ and 900 bar IOP as compared to first phase in modified CRDI diesel engine. The performance of CRDI diesel engine is improved and reduces the emissions except $\mathrm{NO}_{\mathrm{x}}$ emission at MIS of 40-20-40 by increasing the IOP from 600 bar to 900 bar due to better atomization and improved mixing quality of air - fuel mixture in the modified combustion chamber. The higher injection pressure reduces viscosity of POME biodiesel could be the reason to improve the performance of engine.

However, diesel fuel showed higher performance than lower emissions except $\mathrm{NO}_{\mathrm{x}}$ emission as compared to POME operated multiple and single injection strategies in modified CRDI diesel engine. This is due to higher calorific value and lower viscosity of diesel fuel. The higher BTE may be the reason to increase in the $\mathrm{NO}_{\mathrm{x}}$ emission.

On the whole, the POME operated MIS of 40-20-40 showed overall better performance in terms of higher BTE with reduced emissions at $-10^{\circ}$ BTDC and 900 bar IOP in 
modified CRDI diesel engine. The huge burden on the foreign exchange can be saved by using alternative fuel as POME to meet the energy requirement of India and become self sustainable in energy production as well.

\section{Nomenclature}

\begin{tabular}{ll} 
ATDC & After Top Dead Centre \\
BDF & Biodiesel Fuel \\
BP & Brake Power \\
BTDC & Before Top Dead Centre \\
BSFC & Brake Specific Fuel Cosumption \\
CO & Carbon Monoxide \\
CR & Compression Ratio \\
CD & Combustion Duration \\
CCC & Cylindrical combustion chamber \\
CRDI & Common Rail Direct Injection \\
DF & Diesel fuel \\
ECU & Electronic Control Unit \\
HCC & Hemispherical Combustion Chamber \\
HRR & Heat Release Rate \\
IT & Injection Timing \\
IOP & Injection Opening Pressure \\
ID & Ignition Delay \\
JOME & Jatropha Oil Methyl Ester \\
MIS & Multiple Injection Strategy \\
NO & Oxides of Nitrogen \\
POME & Palm oil Methyl Ester \\
PP & Peak Pressure \\
SFC & Specific Fuel Consumption \\
SCC & Shallow Depth Combustion Chamber \\
SIS & Single Injection Strategy \\
TCC & Toroidal Combustion Chamber \\
TRCC & Toroidal reentrant combustion chamber \\
UBHC & Unburnt Hydro Carbon \\
& \\
\hline
\end{tabular}

\section{References}

[1] S. Jaichandar, K Annamalai, "Jatropha oil methyl ester as diesel engine fuel - an experimental investigation," International Journal of Automotive and Mechanical Engineering, 13 (2006) 3248-3261.

[2] F. Sundus, H. H. Masjuki, M. A. Fazal, "Analysis of tribological properties of palm biodiesel and oxidized biodiesel blends," Tribology Transactions, 60 (2017) 530-536.

[3] Zuhaira Abdullah, HazrulzurinaSuhaimi, Adam Abdullah, MohdFirdausTaufik, G. Anes Mrwan, "Effect of pentanoldiesel fuel blends on thermo-physical properties, combustion characteristics, engine performance and emissions of a diesel engine," International Journal of Automotive and Mechanical Engineering, 15 (2018) 5435-5450.

[4] S. N. Naik, V. Vaibhav, K. Goud Prashant, Rout Ajay, K. Dalai, "Production of first and second generation biofuels a comprehensive review," Renewable and Sustainable Energy Reviews, 14 (2010) 578-597.

[5] M. N. Mohiddin, A. A. Saleh, ANR Reddy, S. Hamdan, "A study on chicken fat as an alternative feedstock: biodiesel production, fuel Characterization and diesel engine performance analysis," International Journal of Automotive and Mechanical Engineering, 15 (2018) 5535-5546.

[6] M. Mani, G. Nagarajan, S. Sampath, "Characterization and effect of using waste plastic oil and diesel fuel blends in compression ignition engine," Energy, 36 (2011) 212-219.

[7] A. Atmanli, E. Ileri, B. Yuksel, "Experimental investigation of engine performance and exhaust emissions of a diesel engine fueled with diesel-n-butanol vegetable oil blends," Energy Conversion Management, 81 (2014) 312-21.

[8] A. T. Hoang, M. M. Noorand, X. D. Pham, "Comparative analysis on performance and emission Characteristic of diesel engine fueled with heated coconut oil and diesel Fuel, "International Journal of Automotive and Mechanical Engineering, 15 (2018) 5110-5125.

[9] A. Gautam, A. K. Agarwal, "Experimental investigations of comparative performance, emission and combustion characteristics of cotton seed biodiesel-fueled four-stroke locomotive diesel engine," International Journal of Engine Research, 14 (2013) 354-72.

[10] S. Dixit, A. Rehman, "Linseed oil as a potential resource for bio-diesel: a review," Renewable Sustainable Energy Reviews, 16 (2012) 4415-21.

[11] D. Kannan, S. Pachamuthu, N. M. Nurun, J. E. Hustad, T. Lovas, "Theoretical and experimental investigation of diesel engine performance, combustion and emissions analysis fuelled with the blends of ethanol, diesel and jatropha methyl ester," Energy Conversion Management, 53 (2012) 322-331.

[12] G. Venkata Subbaiah, K. Raja Gopal, "An experimental investigation on the performance and emission characteristics of a diesel engine fuelled with rice brain biodiesel and ethanol blends," Green Energy, 8 (2011) 197-208.

[13] Abhishek Sharma, S. Murugan, "Investigation on the behavior of a DI diesel engine fuelled with jatropha methyl ester (JME) and tyre pyrolysis Oil (TPO) blends," Fuel, 108 (2013) 699708 .

[14] Aydin, Huseyin, CumaliLlkılıc, "Analysis of combustion, performance and emission characteristics of a diesel engine using low sulfur tire fuel," Fuel, 143 (2015) 373-82.

[15] K. Bhaskar, S. Sendilvelan, "Experimental studies on the performance and emission characteristics of a compression ignition engine fuelled with jatropha oil methyl ester," Journal of Mechanical Engineering and Sciences, 12 (2018) 3431-3450.

[16] M. M. Roy, "Effect of fuel injection timing and injection pressure on combustion and odorous emissions in DI diesel engine," Energy Resources Technology, 131 (2009) 1-8.

[17] S. Bari, C. H. Yu, T. H. Lim, "Effect of fuel injection timing with waste cooking oil as a fuel in direct injection diesel engine," Proceedings of the Institution of Mechanical Engineers, Part D, Journal of Automobile Engineering, 218 (2004) 93-104.

[18] N. R. Banapurmath, P. G. Tewari, V. N. Gaitonde, "Experimental investigations on performance and emission characteristics of Honge oil biodiesel (HOME) operated compression ignition engine," Renewable Energy, 48 (2012) 193-201. 
[19] Abhishek Sharma, S. Murugan, "Combustion, performance and emission characteristics of a DI diesel engine fuelled with non-petroleum fuel: A study on the role of fuel injection timing," Energy Institute, 88 (2015) 364-75.

[20] G. Suresh, H. C. Kamath, N. R. Banapurmath, "Effect of injection timing, injector opening pressure and nozzle geometry on the performance of cotton seed oil methyl ester fuelled diesel engine," Sustainable Engineering, 7 (2013) 8292.

[21] S. Rostami, B. Ghobadian, M. Kiani Deh Kiani, "Effect of the injection timing on the performance of a diesel engine using diesel-biodiesel blends," International Journal of Automotive and Mechanical Engineering, 10 (2014) 1945-1958.

[22] Karra, K. Prashanth, Song Charng Kong, "Experimental study on effects of nozzle holes geometry on achieving low diesel engine emissions,"Engineering for Gas Turbines and Power, $132(2010) 022802$.

[23] Lahane, Subhash, K. A. Subramanian, "Impact of nozzle holes configuration on fuel spray, wall impingement and $\mathrm{NO}_{x}$ emission of a diesel engine for biodiesel-diesel blend (B20),"Applied Thermal Engineering, 64 (2014) 307-314.

[24] S. V. Khandal, N. R. Banapurmath, V. N. Gaitonde, R. S. Hosmath, "Effect of number of injector nozzle holes on the performance, emission and combustion characteristics of honge oil biodiesel (HOME) Operated DI compression Ignition Engine," Petroleum and Environmental Biotechnology, 6 (2015) 1-18.

[25] S. P. Wategave, M. S. Sawant, M. S. Tandale, G. Suresh, V. S. Yaliwalc, N. R. Banapurmath, P. G. Tewari, "Effect of injection timing, injector opening pressure and nozzle geometry on the performance of a compression ignition engine operated on non-edible oil methyl esters from different sources," Sustainable Engineering, 1 (2014) 71-81.

[26] S. Jaichandar, K. Annamalai, "Effects of open combustion chamber geometries on the performance of pongamia biodiesel in a DI diesel engine," Fuel, 98 (2012) 272-279.

[27] S. Jaichandar S, K. Annamalai, "Combined impact of injection pressure and combustion chamber geometry on the performance of a biodiesel fueled diesel engine," Energy, 55 (2013) 330-339.

[28] N. R. Banapurmath, A. S. Chavan, S. B. Bansode, Sankalp Patil, G. Naveen, Sanketh Tonannavar, N. K. Keerthi, M. S. Tandale, "Effect of combustion chamber shapes on the performance of mahua and neem biodiesel operated diesel engine," Petroleum and Environmental Biotechnology, 6 (2015) 1-7.

[29] MahanteshM. Shivashimpi, S. A. Alur, S. N. Topannavar, B. M. Dodamani, "Combined effect of cylindrical combustion chamber shape and nozzle geometry on the performance and emission characteristics of C.I. engine operated on pongemia," Mechanical engineering for sustainable development state of the art research, USA: Apple Academic Press, CRC press, Taylor and Francis Group, (2018) 345359 .

[30] MahanteshM. Shivashimpi, S. A. Alur, S. N. Topannavar, B. M. Dodamani, "Combined effect of combustion chamber shapes and nozzle geometry on the performance and emission characteristics of C.I. engine operated on Pongamia," Energy, 154 (2018) 17-26.
[31] Mobasheri, Raouf, ZhijunPeng, "CFD investigation of the effects of re-entrant combustion chamber geometry in a HSDI diesel engine," Scientific Research Innovation, 7 (2013) 770780 .

[32] S. Jaichandar, P. Senthil Kumar, K. Annamalai, "Combined effect of injection timing and combustion chamber geometry on the performance of a biodiesel fueled diesel engine," Energy, 47.1 (2012) 388-394.

[33] V. S. Yaliwal, N. R. Banapurmath, N. M. Gireesh, R. S. Hosmath, Teresa Donateo, P. G. Tewari, "Effect of nozzle and combustion chamber geometry on the performance of a diesel engine operated on dual fuel mode using renewable fuels," Renewable Energy, 93 (2016) 483-501.

[34] Venkata Ramesh Mamilla, M. V. Mallikarjun, G. Lakshmi NarayanaRao, "Effect of combustion chamber design on a DI diesel engine fuelled with jatropha methyl esters blends with diesel," Procedia Engineering, 64 (2013) 479-490.

[35] Vinay Kumar, "Experimental investigation of piston bowl geometry effects on performance and emissions characteristics of diesel engine at variable injection pressure and timings," Ambient Energy, 39 (2018) 685-693.

[36] M. M. Shivashimpi, N. R. Banapurmath, S. A. Alur, S. V. Khandal, "Effect of combustion chamber shapes, nozzle holes geometries, injection pressures and injection timing on the performance diesel engine fueled with palm oil methyl ester," European Journal of Sustainable Development Research, 2 (2018) 1-17.

[37] SrinathPai, Abdul Sharief, Shiva Kumar, "Influence of ultra injection pressure with dynamic injection timing on CRDI engine performance using simarouba biodiesel blends," International Journal of Automotive and Mechanical Engineering, 15 (2018) 5748-5759.

[38] D. H. Qi, K. Yang, D. Zhang, B. Chen, Q. Wei, C. H. Zhang, "Experimental investigation of a turbocharged CRDI diesel engine fueled with tung oil-diesel-ethanol micro emulsion fuel," Renewable Energy, 113 (2017) 1201-1207.

[39] C. Syed Aalam, C. G. Saravanan, B. Prem Anand, "Impact of high fuel injection pressure on the characteristics of CRDI diesel engine powered by mahua methyl ester blend," Applied Thermal Engineering, 106 (2016) 702-711.

[40] S. V. Khandal, N. R. Banapurmath, V. N. Gaitonde, V. S. Yaliwal, "Common rail direct injection mode of CI engine operation with different injection strategies - a method to reduce smoke and $\mathrm{NO}_{\mathrm{x}}$ emissions simultaneously," European Journal of Sustainable Development Research, 2 (2018) 1-18.

[41] S. Karthikeyan, T. Dharma Prabhakaran, A. Prathima, "Environment effect of $\mathrm{La} 2 \mathrm{O} 3$ nano-additives on microalgaebiodiesel fueled CRDI engine with conventional diesel," Energy Sources Part A: Recovery Utilization and Environmental Effects, 40 (2018) 179-185.

[42] D. I. Silvana Iorio, Ezio Mancaruso, M. Bianca Vaglieco, "Characterization of soot particles produced in a transparent research CRDI diesel engine operating with conventional and advanced combustion strategies," Aerosol Science and Technology, 46 (2012) 272-286.

[43] Shukla, A. D. Shetty, A. J. Antony, "Performance and emission characteristics of CRDI engine working on plastic oil," Indian journal of science and technology, 9 (2016) 1-6. 
[44] Avinash Kumar Agarwal, AtulDhar, Jai Gopal Gupta, WoongKim, Kibong Choi, Chang Sik Lee, Sungwook Park, "Effect of fuel injection pressure and injection timing of Karanja biodiesel blends on fuel spray, engine performance, emissions and combustion characteristics," Energy Conversion and Management, 91 (2015) 302-314.

[45] Avinash Kumar Agarwal, AtulDhar, Jai Gopal Gupta, WoongKim, Chang Sik Lee, SungwookPark, "Effect of fuel injection pressure and injection timing on spray characteristics and particulate size-number distribution in a biodiesel fuelled common rail direct injection diesel engine," Applied Energy, 130 (2014) 212-221.

[46] D. H. Qi, K. Yang, D. Zhang, B. Chen, "Combustion and emission characteristics of diesel-tung oil-ethanol blended fuels used in a CRDI diesel engine with different injection strategies," Applied Thermal Engineering, 111 (2017) 927935.

[47] AtulDhar, Avinash Kumar Agarwal, "Experimental investigations of the effect of pilot injection on performance, emissions and combustion characteristics of Karanja biodiesel fuelled CRDI engine," Energy Conversion and Management, 93 (2015) 357-366.

[48] M. Mikulski, K. Duda, S. Wierzbicki, "Performance and emissions of a CRDI diesel engine fuelled with swine lard methyl esters-diesel mixture," Fuel, 164 (2016) 206-219.

[49] Khairul Azly Zahan, Manabu Kano, "Biodiesel production from palm oil, its by-products, and mill effluent: a review," Journal of Energies 11 (2018) 1-25.

[50] S. O. Kareem, E. I. Falokun, S. A. Balogun, O. A. Akinloye, S. O. Omeike, "Enzymatic biodiesel production from palm oil and palm kernel oil using free lipase," Egyptian Journal of Petroleum, 26 (2017) 635-642.

[51] S. Kevin Chen, "Simultaneous reduction of $\mathrm{NO}_{\mathrm{x}}$ and particulate emissions by using multiple injections in a small diesel engine," SAE, 01 (2000) 1-10.

[52] B. P. Pattanaik, J. Jena, R. D. Misra, "The effect of oxygen content in soapnut biodiesel-diesel blends on performance of a diesel engine," International Journal of Automotive and Mechanical Engineering, 14 (2017) 4574-4588.

[53] M. Mikulski, k. Duda, S. Wierzbicki, "Performance and emissions of a CRDI diesel engine fuelled with swine lard methyl esters-diesel mixture,"Fuel, 164 (2016) 206-219.

[54] C. S. Lee, S. W. Park, "An experimental and numerical study on fuel atomization characteristics of high pressure diesel injection sprays," Fuel, 81 (2002) 2417-2423.

[55] N. M. Taib, M. S. Zainuddin, MRA. Mansor, Z. Ilham, "Performance and emission opacity of canola and soybean biodiesel fuel in a diesel engine," Journal of Mechanical Engineering and Sciences, 12 (2018) 3689-369.

[56] V. Khalid, ASA. Tajuddin, N. Jaat, B. Manshoor, I. Zaman, SAA. Hadi, R. S. Nursal, "Performance and emissions of diesel engine fuelled with preheated biodiesel fuel derived from crude palm, jatropha, and waste cooking oils," International Journal of Automotive and Mechanical Engineering, 14 (2017) 4273-4284.

[57] NorrizamJaat, Amir Khalid, Mariam Basharie, Azahari Razali, Azwan Sapit, Z. Noranai, "Influences of the end of injection and ambient temperature on biodiesel combustion, "Journal of Mechanical Engineering and Sciences, 11 (2017) 2883-2994. 